\title{
Targeted disruption of the murine VCAM1 gene: essential role of VCAM-1 in chorioallantoic fusion and placentation
}

\author{
Geoffrey C. Gurtner, ${ }^{1}$ Vannessa Davis, ${ }^{1}$ Hongmei Li, ${ }^{1}$ Michael J. McCoy,, Arlene Sharpe, ${ }^{2}$ \\ and Myron I. Cybulsky, ${ }^{1,3}$ \\ ${ }^{1}$ Vascular and ${ }^{2}$ Immunology Research Divisions, Department of Pathology, Brigham and Women's Hospital, Harvard Medical \\ School, Boston, Massachusetts 02115 USA
}

\begin{abstract}
Vascular cell adhesion molecule-1 (VCAM-1) is expressed on vascular endothelium in a variety of inflammatory conditions and mediates leukocyte recruitment from blood into tissues. In this study we report a novel role for VCAM-1 in the formation of the umbilical cord and placenta during development. The murine VCAM1 gene was disrupted by targeted homologous recombination, and a distinct phenotype was found in VCAM-1-deficient embryos. At 8.5 days of gestation, the allantois failed to fuse to the chorion, resulting in abnormal placental development and embryonic death within 1-3 days. In addition, a role for VCAM-1 in early placental formation after chorioallantoic fusion was observed. In a minority of VCAM-1-deficient embryos, the allantois was able to fuse with the chorion, but the allantoic mesoderm was abnormally distributed over the chorionic surface. A small number of VCAM-1-deficient embryos survived, presumably by circumventing the placentation defects. They became viable and fertile adult mice with lack of VCAM-1 expression, normal organs, and an elevated number of circulating blood mononuclear leukocytes.
\end{abstract}

[Key Words: VCAM-1; allantois; chorioallantoic fusion; placentation; $\alpha 4$ integrins]

Received October 4, 1994; revised version accepted October 27, 1994.

Vascular cell adhesion molecule-1 (VCAM-1) is a transmembrane glycoprotein member of the immunoglobulin gene superfamily (Osborn et al. 1989). Similarities to ICAM-1 in structure and leukocyte adhesive function provided the clue that led to identification of $\alpha 4 \beta 1$ (VLA4; CD49d/CD29) and subsequently $\alpha 4 \beta 7$ integrins as its ligands (Elices et al. 1990; Chan et al. 1992). Internal homology of VCAM-1 immunoglobulin-like domains (1-3 and 4-6), which likely arose by duplication of an ancestral gene (Cybulsky et al. 1991), accounts for two $\alpha 4$ integrin-binding sites on each VCAM-1 molecule (Osborn et al. 1992). Alternative RNA splicing can result in forms with only one $\alpha 4$ integrin-binding site.

VCAM-1 is expressed on a variety of vascular and nonvascular cells, where its primary function is to mediate intercellular adhesion. On vascular endothelium, expression is inducible by cytokine activation and VCAM-1 promotes $\alpha 4$-integrin-bearing leukocyte adhesion (Carlos et al. 1990; Rice et al. 1991). In vivo endothelial cell expression of VCAM-1 is found in a variety of inflammatory and immune conditions, including atherosclerosis (Cybulsky and Gimbrone 1991; O'Brien et al. 1993) and allograft rejection (Briscoe et al. 1991), and in these settings, VCAM-1 is thought to participate in mediating

${ }^{3}$ Corresponding author. inflammatory leukocyte recruitment. In addition to endothelium, inducible expression of VCAM-1 is found in vascular smooth muscle cells (Li et al. 1993). VCAM-1 is constitutively expressed on lymphoid dendritic cells, where it is involved in B-lymphocyte adhesion and may participate in the formation of lymphoid follicles (Freedman et al. 1990). On antigen-presenting cells (dendritic and endothelial cells), VCAM-1 may act as a T-cell costimulatory molecule (Burkly et al. 1991; Damle and Aruffo 1991; van Seventer et al. 1991). Expression on bone marrow stromal cells may contribute to the maturation of hematopoietic cells (Miyake et al. 1991; Simmons et al. 1992).

As in inflammation, intercellular adhesion is thought to be important in cellular migration and organization during embryonic development. Antibody-blocking studies have revealed a role for E-cadherin in preimplantation blastocyst compaction and cavitation (Damsky et al. 19831, which has been confirmed by targeted disruption of the murine E-cadherin gene (Larue et al. 1994). Similarly, a wide variety of integrins and extracellular matrix ligands have been implicated in trophoblast differentiation and invasion (Damsky et al. 1993). VCAM-1 has only been implicated in later events during development. Through its interactions with $\alpha 4$ integrins, it has been shown to participate in secondary myogenesis (Rosen et al. 1992). VCAM-1 expression has been de- 
scribed in the developing mouse myocardium and muscularis of the stomach, leading to speculation regarding its possible involvement in cardiac and alimentary development (Sheppard et al. 1994).

Most research on placentation has focused on cellular events involving trophoblast invasion of the uterus (Welsh and Enders 1993), immunological maternal-fetal interactions (Kovats et al. 1990), and changes produced in the maternal vasculature as a result of implantation (Ogura et al. 1991). Conversely, little is understood regarding the development of the fetal placental vascular system from undifferentiated fetal allantoic mesoderm (Pijnenborg et al. 1981). The complexity of the definitive hemochorial placenta in rodents and humans is comparable to the other developing embryological systems (i.e., cardiovascular, urogenital, etc.) and implies a precise orchestration of cellular adhesion and migration.

In this study we provide new insights into the mechanism of placentation and umbilical cord formation. Using homologous recombination in embryonic stem (ES) cells, we inactivated the murine VCAM1 gene and determined an essential and novel role for VCAM-1 in embryogenesis-fusion of the allantois to the chorion. This mid-gestational event is required for umbilical cord and placental development and is necessary for maternal- fetal nutrient/gas exchange and, ultimately, for intrauterine survival.

\section{Results}

\section{Generation of VCAM-1-deficient mice}

The murine VCAM1 gene was disrupted by homologous recombination in ES cells (Thomas and Capecchi 1987; Mansour et al. 1988; McMahon and Bradley 1990). The strategy was to delete most of the first immunoglobulinlike domain, critical to VCAM-1 function /Osborn et al. 1992). Alternatively spliced forms of VCAM-1 lacking domain 1 have not been observed. The VCAM1 gene was cloned from a J1 ES cell genomic library (Cybulsky et al. 1993), and a targeting construct was assembled from a 6.7-kb EcoRI genomic clone at the 5' portion of the gene containing the core promoter and the first four exons encoding the signal peptide and immunoglobulin-like domains 1-3 (Fig. 1A). Exon 2, encoding domain 1, was disnupted by deleting the majority of this domain and a portion of the following intron with restriction enzymes BgIII and NheI. At this site, a neomycin resistance cassette (NEO) was inserted in the opposite transcriptional orientation to VCAM1. Homologous regions of the
Figure 1. Design of the VCAM1 targeting construct and Southern blot analysis of ES cell clones. $(A)$ VCAM1 wild-type allele, targeting construct, and targeted homologous recombination at the VCAM1 locus. The targeting construct was assembled from a 6.7-kb EcoRI genomic clone containing the first four exons ( $\square$ ). The majority of the first immunoglobulin-like domain (DI) and a portion of the following intron were removed by BgIII and NheI restriction enzymes and replaced by the NEO cassette in the opposite transcriptional orientation to VCAM1. A herpes simplex virus TK cassette was inserted at the $5^{\prime}$ end, and the construct was linearized by digestion with NotI. ( $\square$ ) Probes used for Southern blotting. (B) BamHI; (RI) EcoRI; (X) XhoI. (B) Representative lanes from Southern blots of DNA obtained from expanded ES cell clones. The 5' probe (0.5-kb EcoRI-PstI fragment) was used to screen G418-resistant colonies for targeted homologous recombination at the VCAM1 locus. The 7.0- and 5.0-kb bands represent the wild-type and targeted alleles, respectively. Single integration of the targeting construct was verified with a NEO probe (8.7-kb band), and appropriate integration at the $3^{\prime}$ end was confirmed with a probe $3^{\prime}$ to the targeting construct $(12.3-\mathrm{kb}$ band). Arrowheads indicate lanes with targeted homologous recombination.

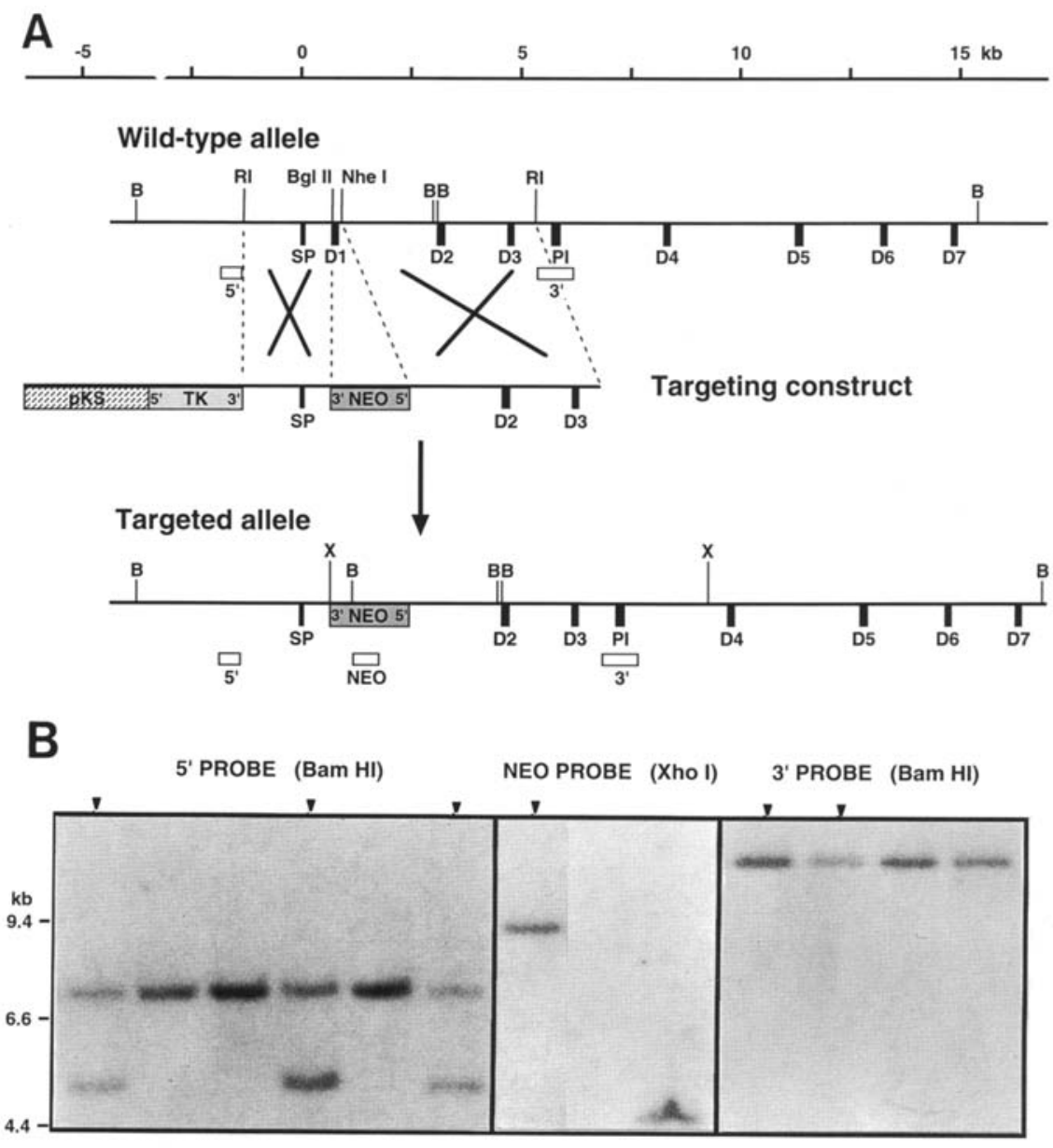


VCAM1 gene $5^{\prime}$ and $3^{\prime}$ of NEO were 2.0 and $4.3 \mathrm{~kb}$, respectively. For negative selection against random integration of the targeting construct, a herpes simplex virus thymidine kinase (TK) cassette was inserted at the $5^{\prime}$ end of the construct (Mansour et al. 1988).

The linearized targeting construct was electroporated into murine J1 ES cells (Li et al. 1992), and ES cells were selected using G418 and the pyrimidine analog FIAU (McMahon and Bradley 1990). Homologous recombination frequency at a single VCAM1 allele was $7.6 \%$ (13 of 170 antibiotic-resistant ES cell colonies|, determined by Southern blotting (Fig. 1B). Single integration of the targeting construct and appropriate recombination at the $5^{\prime}$ and $3^{\prime}$ ends were verified by Southern blotting (Fig. 1B). Seven mutant clones were injected into $\mathrm{C} 57 \mathrm{BL} / 6$ and $\mathrm{BALB} / \mathrm{c}$ recipient blastocysts, and male offspring exhibiting extensive coat chimerism (founder males) were subsequently mated to wild-type C57BL/6, BALB/c, and 129 females. Germ-line transmission of the disrupted VCAM1 allele was achieved for the first three clones injected (V16, V44, and V80), and these were used for the remainder of the study. $F_{1}$ mice heterozygous for the disrupted VCAM1 allele appeared phenotypically normal (size, general health, fertility, and longevity of $>1.5$ years) in all three backgrounds.
Mice homozygous for the disrupted VCAM1 allele die during mid-gestation

Mating of $F_{1}$ and $F_{2}$ mice heterozygous for the disrupted VCAM1 allele in the 129/C57BL/6, 129/BALB/c, and pure 129 strains revealed a striking paucity of homozygous VCAM-1-deficient mice surviving at term $\mid<1 \%$ total), indicating a recessive lethal phenotype (Table 1). Genotyping of embryos derived from timed pregnancies demonstrated an alteration in the expected Mendelian distribution. Instead of $25 \%$, a decreased number of VCAM-1-deficient embryos was found by 12.5 days postcoitum (p.c.) or earlier, accompanied by an increased number of phenotypic abnormalities and necrotic implantation sites (Table 1). All 12.5 days p.c., VCAM-1deficient embryos showed histologic evidence of cell death and tissue necrosis. These data indicated that absence of VCAM-1 results in mid-gestational demise of embryos.

\section{Absence of chorioallantoic fusion} in VCAM-1-deficient embryos

In VCAM-1-deficient embryos, the sequence of events following implantation, including gastrulation and neu-

Table 1. Genotype of offspring from heterozygous parents

\begin{tabular}{|c|c|c|c|c|c|c|}
\hline \multirow{2}{*}{$\begin{array}{l}\text { Days } \\
\text { postcoitum }\end{array}$} & \multirow{2}{*}{$\begin{array}{l}\text { Implantation } \\
\text { sites }^{\mathbf{a}}\end{array}$} & \multirow{2}{*}{$\begin{array}{l}\text { Total } \\
\text { embryos }\end{array}$} & \multicolumn{3}{|c|}{ Genotype of live and resorbing embryos } & \multirow{2}{*}{$\begin{array}{l}\text { Phenotype of } \\
-/ \text { - embryos }\end{array}$} \\
\hline & & & $+1+$ & $+1-$ & $-1-$ & \\
\hline \multicolumn{7}{|c|}{$129 / B A L B / c$ strain } \\
\hline 7.5 & 0 & 35 & 12 & 16 & 7 & \multirow{6}{*}{$\begin{array}{l}(4)^{\mathrm{b}} \\
(8)^{\mathrm{b}} \\
(1)^{\mathrm{c}}(4)^{\mathrm{d}} \\
(4)^{\mathrm{d}}\end{array}$} \\
\hline 8.5 & 3 & 31 & 11 & 14 & 6 & \\
\hline 9.5 & 2 & 31 & 10 & 13 & 8 & \\
\hline 10.5 & 7 & 41 & 9 & 27 & 5 & \\
\hline 12.5 & 7 & 31 & 11 & 16 & 4 & \\
\hline Term & & 72 & 22 & 49 & 1 & \\
\hline \multicolumn{7}{|c|}{ 129/C57BL/6 strain } \\
\hline 7.5 & 1 & 27 & 5 & 16 & 6 & \multirow{6}{*}{$\begin{array}{l}(6)^{\mathrm{b}} \\
(6)^{\mathrm{b}}(4)^{\mathrm{e}}(2)^{\mathrm{c}}(1)^{\mathrm{f}} \\
(2)^{\mathrm{b}},(3)^{\mathrm{c}}(2)^{\mathrm{d}}(2)^{\mathrm{f}} \\
(1)^{\mathrm{c}},(5)^{\mathrm{d}}(2)^{\mathrm{g}}\end{array}$} \\
\hline 8.5 & 1 & 63 & 18 & 34 & 11 & \\
\hline 9.5 & 8 & 58 & 18 & 27 & 13 & \\
\hline 10.5 & 9 & 39 & 9 & 21 & 9 & \\
\hline 12.5 & 9 & 50 & 17 & 25 & 8 & \\
\hline Term & & 156 & 55 & 99 & 2 & \\
\hline \multicolumn{7}{|c|}{129 strain } \\
\hline 8.5 & 1 & 26 & 7 & 12 & 8 & \multirow{6}{*}{$\begin{array}{l}(4)^{\mathrm{b}}(1)^{\mathrm{e}}(1)^{\mathrm{c}} \\
(2)^{\mathrm{b}}(2)^{\mathrm{e}} \\
(5)^{\mathrm{b}}(2)^{\mathrm{f}} \\
(3)^{\mathrm{c}}(2)^{\mathrm{d}}\end{array}$} \\
\hline 9.5 & 1 & 27 & 5 & 16 & 6 & \\
\hline 10.5 & 6 & 24 & 8 & 12 & 4 & \\
\hline 11.5 & 4 & 27 & 7 & 13 & 7 & \\
\hline 12.5 & 5 & 29 & 10 & 15 & 4 & \\
\hline Term & & 103 & 27 & 76 & 0 & \\
\hline
\end{tabular}

amplantation sites were excluded from genotyping.

bAllantois not fused, hydropic.

${ }^{c}$ Allantois not fused, embryo dead with early resorption.

dAllantois not fused, embryo dead with extensive resorption.

eAllantois not fused, solid.

${ }^{f}$ Allantois fused.

gAllantois fused with abnormal placental vasculature and generalized developmental delay. 
rulation, proceeded normally. However, at 8.5 days p.c., a failure of fusion of the embryonic allantois to the chorion occurred in VCAM-1-deficient embryos (Fig. 2A). By 9.0-9.5 days p.c., an unfused allantois underwent marked hydropic expansion and this distinct phenotype was clearly evident (Fig. 2B). The embryos turned normally, and no other developmental defects were found at this stage (Fig. $2 \mathrm{C}$ ). Connection to the yolk sac vasculature via vitelline vasculature was normal, as was yolk sac blood vessel formation and hematopoiesis. Subsequently, hydropic allantoides became compact, embryos died within 1-3 days, and began resorbing. Despite the absence of chorioallantoic fusion in VCAM-1-deficient embryos, the allantoic mesoderm was able to differentiate into vascular structures (Fig. 2D).

In wild-type embryos, mesenchyme derived from the posterior primitive streak forms the allantois, which grows from the caudal region of the embryo across the exocoelomic cavity toward the chorionic plate (Theiler 1989|. The allantois fuses with the chorion at 8.0-8.5 days p.c., and, subsequently, the allantoic mesoderm forms the embryonic vasculature of the developing placenta (Rossant and Croy 1985). The mesoderm of the allantoic stalk differentiates to form an umbilical cord containing arterial and venous blood vessels. In VCAM1-deficient embryos, the absence of chorioallantoic fu- sion prevented maternal-embryo respiratory and nutritional exchange and resulted in embryonic death within 1-3 days. A similar outcome has been observed in embryos with agenesis or hypogenesis of the allantois and, thus, absent chorioallantoic fusion (Chesley 1935; Valshtrem 1960; Vickers 1985).

Immunohistochemical staining performed on 8.0- to 8.5-day p.c. wild-type embryos, immediately prior to chorioallantoic fusion, revealed expression of VCAM-1 on the tip of the allantois and $\alpha 4$ integrin on the inner surface of the chorionic plate (Fig. 3). The cuboidal cells lining the surface of the allantois appeared to be expressing VCAM-1, whereas the inner mesenchymal-like cells did not. These data suggest that VCAM-1 on the tip of the allantois can interact with $\alpha 4$ on the chorionic surface to mediate chorioallantoic fusion.

At 8.5-9.5 days p.c., the only tissue in wild-type embryos with VCAM-1 expression other than the allantois was the heart, where VCAM-1 was expressed by myocytes of the developing myocardium. Immunohistochemical staining was utilized to demonstrate absence of VCAM-1 protein expression in 9.5-day VCAM-1-deficient embryos, which were identified by an unfused hydropic allantois and by genotyping of yolk sacs (data not shown). Expression of $\alpha 4$ integrin was not detected in the heart at this time.
Figure 2. Absence of chorioallantoic fusion in VCAM-1-deficient embryos. $(A, B)$ Homozygous VCAM-1-deficient mouse embryos in the process of turning at 8.5 days gestation $(A)$ and after turning at 9.0 days $(B)$, showing a hydropic allantois that is not fused to the chorion. $(C)$ Embryos 10.5 days p.c. demonstrating normal size variability within a litter. The two embryos at left have a hydropic unfused allantois and are homozygous for the disrupted VCAM1 allele. No other abnormalities were found at this stage of development. The two embryos at right are heterozygous and have undergone chorioallantoic fusion. In the far right embryo, the placenta and attached allantois were separated to expose the placental surface. An umbilical vessel is evident (arrowhead). (D) A 10.5-day VCAM-1-deficient embryo showing two blood vessels formed in the unfused allantois (arrowheads).
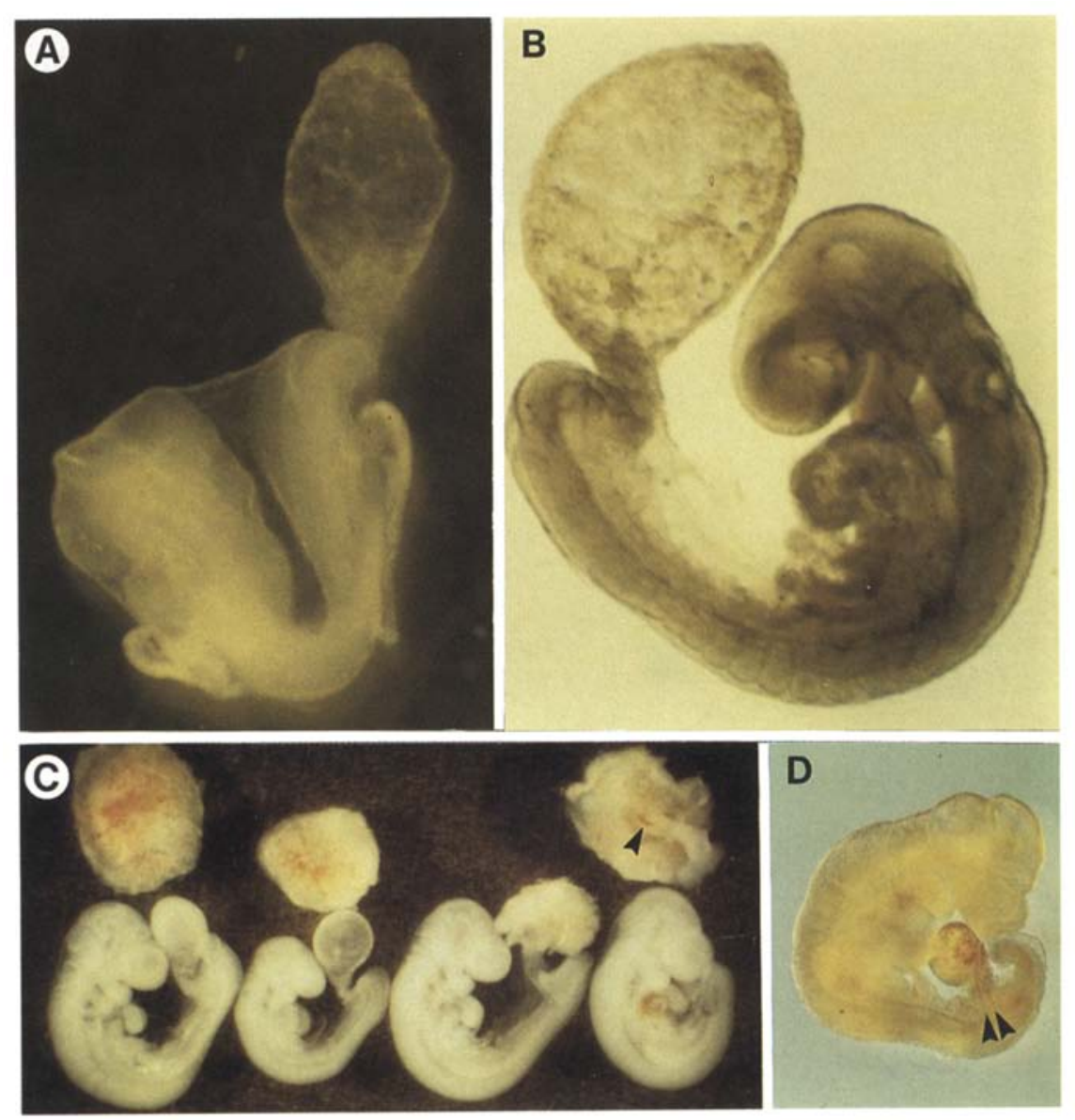


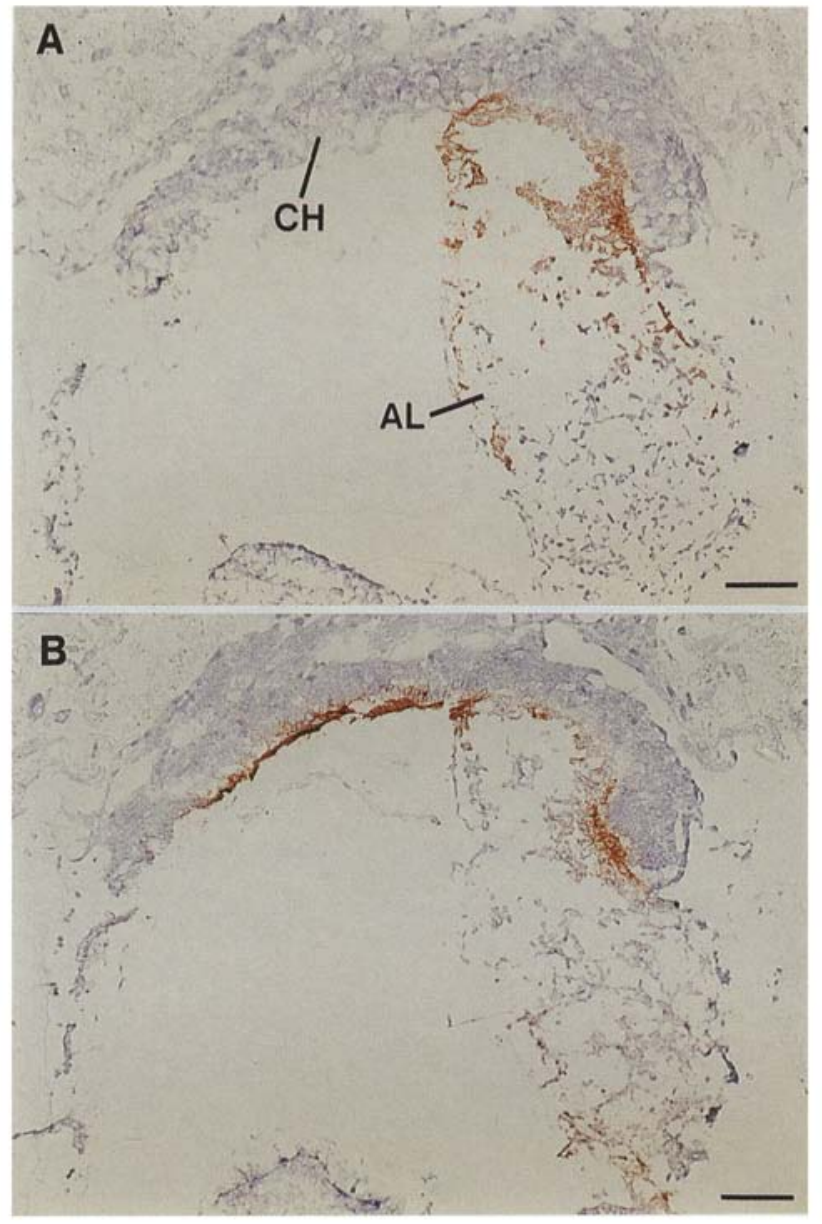

Figure 3. VCAM-1 and $\alpha 4$ integrin expression during chorioallantoic fusion. $(A)$ VCAM-1 expression at the tip of the allantois demonstrated by MK-2 immunohistochemical staining (red) in a wild-type C57BL/6 mouse embryo at $8.0-8.5$ days gestation. The tip of the allantois $(A L)$ is in contact with the chorion $(\mathrm{CH})$. Bar, $100 \mu \mathrm{m}$. (B) A serial section showing $\alpha 4$ integrin expression (PS-2 staining) along the entire surface of the chorion.

\section{Role of VCAM-1 in placental formation}

after chorioallantoic fusion

All embryos of timed pregnancies summarized in Table 1 were carefully dissected with particular attention given to determine whether chorioallantoic fusion had occurred. In the 129/C57BL/ 6 background, chorioallantoic fusion was found in $17 \%$ of VCAM-1-deficient embryos, and in the 129 background, the frequency was $9 \%$ (Table 1). None were found in the 129/BALB/c background. Fused VCAM-1-deficient embryos appeared to develop and survive 1-2 days longer than VCAM-1-deficient embryos without chorioallantoic fusion; however, at 12.5 days p.c. they were dead. Histologic sections through these embryos showed extensive tissue necrosis, precluding detailed analysis of organs (not shown). Because, in mid-gestational embryos, VCAM-1 is ex- pressed during placentation and in the developing heart, the possibilities of placental or cardiac defects were investigated.

In wild-type embryos, we observed that within hours of chorioallantoic fusion, the allantoic mesoderm covered the entire placental surface. The fused allantois assumed a funnel configuration containing a large hydropic space (Fig. 4A). This is in agreement with descriptions of this process published previously (Ellington 1985). Immunohistochemical staining shortly after chorioallantoic fusion revealed VCAM-1 expression in the allantoic mesoderm in contact with the chorionic plate and surrounding the hydropic space (Fig. 4B), and in a serial section, $\alpha 4$ expression was found on the chorionic surface (Fig. 4C). These expression patterns suggest that VCAM-1/ $\alpha 4$ integrin interactions may be necessary for the efficient distribution of allantoic mesoderm over the entire placental surface. The significance of this is that the allantoic mesoderm subsequently differentiates into arborizing vascular channels, which are connected to umbilical vessels (Cinquetti 1983), and invades the trophoblast, forming embryonic blood vessels of the hemochorial placenta (Mossman 1987). A delay in placental formation may have deleterious effects on embryonic development, leading to embryonic defects and even death. The above hypothesis was supported by observations in 10.5- and 11.5-day embryos.

In 10.0- to 10.5-day wild-type and heterozygous embryos, the hydropic space in the allantois was largely resorbed and blood vessel formation was evident in the allantoic mesoderm adjacent to trophoblasts (Fig. 5A,B). In a VCAM-1-deficient littermate, we found an allantois attached to the chorion, with morphologic features suggesting that the hydropic change occurred prior to fusion (Fig. 5A,C). The allantoic mesoderm was not distributed over the entire chorionic surface, and formation of vascular structures lagged in comparison with a heterozygous littermate. Although a central umbilical blood vessel was present, only focal mesodermal invasion was seen at regions where the mesoderm was in contact with the chorion. These features represent a developmental delay of the placenta with respect to the embryo.

At 11.5 days p.c. we found viable VCAM-1-deficient embryos, both with and without chorioallantoic fusion (Table 1, 129 strain). Thin sections revealed delayed development of the placenta in a VCAM-1-deficient embryo (Fig. 6). Unlike wild-type and heterozygous littermates, there was minimal invasion of the placental trophoblast layer by allantoic mesoderm and embryonic blood vessels were virtually absent in the trophoblast.

All viable VCAM-1-deficient embryos also had cardiac abnormalities. Sections showed vacuolation, blebbing, cell rounding, and dissolution of the epicardial layer (Fig. 7). The adjacent thoracic wall appeared normal, and mitotic figures were seen occasionally. Variable vacuolation, blebbing, and rounding were seen in myocardial and endocardial cells, predominantly in embryos without chorioallantoic fusion (not shown). In wild-type and heterozygous littermates, the epicardium and endocardium consisted of a uniform sheet of flat cells (Fig. 7). 
Figure 4. VCAM-1 and $\alpha 4$ integrin expression in wild-type embryos after chorioallantoic fusion. $(A)$ Section of an 8.5-day embryo stained with hematoxyllin and eosin, showing spread of allantoic mesoderm over most of the chorionic surface shortly after chorioallantoic fusion. The allantois has a funnel configuration and contains a central hydropic space (HS). (AL) Allantois; (AM) amnion; (CH) chorion; (T) trophoblast; (EH) embryo head; (UD) uterine decidua; (YS) yolk sac. Bar, $100 \mu \mathrm{m}$. (B) An embryo at a similar developmental stage stained with $\mathrm{mAb}$ MK2. VCAM-1 expression is found in the allantoic mesoderm in contact with the chorion and surrounding the hydropic space. A littermate of this embryo, which had not undergone chorioallantoic fusion, is shown in Fig. 3. Bar, $100 \mu \mathrm{m}$. (C) A serial section showing $\alpha 4$ integrin expression (PS-2 staining) at the junction of allantoic mesoderm and chorion. Intense staining is seen in a cell layer immediately adjacent to the hydropic space (arrowheads), whereas intense VCAM-1 staining is below this (B), suggesting that the cells expressing $\alpha 4$ are derived from the chorion and that the allantoic mesoderm may have penetrated through this layer. At the edges of the chorion not in contact with allantoic mesoderm, $\alpha 4$ integrin expression is found on the surface. Other tissues within the embryo also express $\alpha 4$. Bar, $100 \mu \mathrm{m}$.

\section{Analysis of viable VCAM-1-deficient mice}

In $>300$ offspring of $F_{1}$ and $F_{2}$ heterozygous matings, three viable VCAM-1-deficient mice were identified by Southern blotting of tail DNA. These mice were males, fertile, and indistinguishable in size, weight, general health, activity, and longevity from wild-type or heterozygous littermates. On two occasions during mating, one of the VCAM-1-deficient males developed skin wounds on the back, and these healed readily. The homozygous VCAM-1-deficient male mice were bred with heterozygous females, and of 95 offspring in these litters, an additional VCAM-1-deficient male was identified; all the remaining offspring were heterozygous. When 9.5-day p.c. embryos produced by these matings were examined, the expected Mendelian distribution and chorioallantoic fusion defect were found.

In addition to Southern blot analysis of tail DNA, PCR analysis of blood samples and a portion of the ear was performed on all four VCAM-1-deficient mice and a wild-type VCAM1 allele was not detected (data not shown). To further exclude the possibility of genetic mosaicism in these mice, two were injected with lipopolysaccharide [LPS, $100 \mu \mathrm{g}$ intraperitoneal (i.p.)] $4 \mathrm{hr}$ prior to sacrifice. Various organs were harvested and subjected to Southern blot and PCR analysis that detected only the mutated VCAM1 allele (Fig. 8A). Northern blot analysis of RNA revealed the absence of VCAM-1 transcript in VCAM-1-deficient mice and reduced transcript in heterozygotes (Fig. 8B). Immunohistochemical staining did not detect VCAM-1 protein in the heart, spleen, or lung, although intercellular cell adhesion molecule-1 (ICAM1) expression appeared normal (Fig. 8C-F). Hearts of VCAM-1-deficient mice had normal chamber anatomy and distribution of coronary arteries. Histologic sections showed normal epicardium, myocardium, and endocardium (Fig. 7C). Gross and histologic examination of

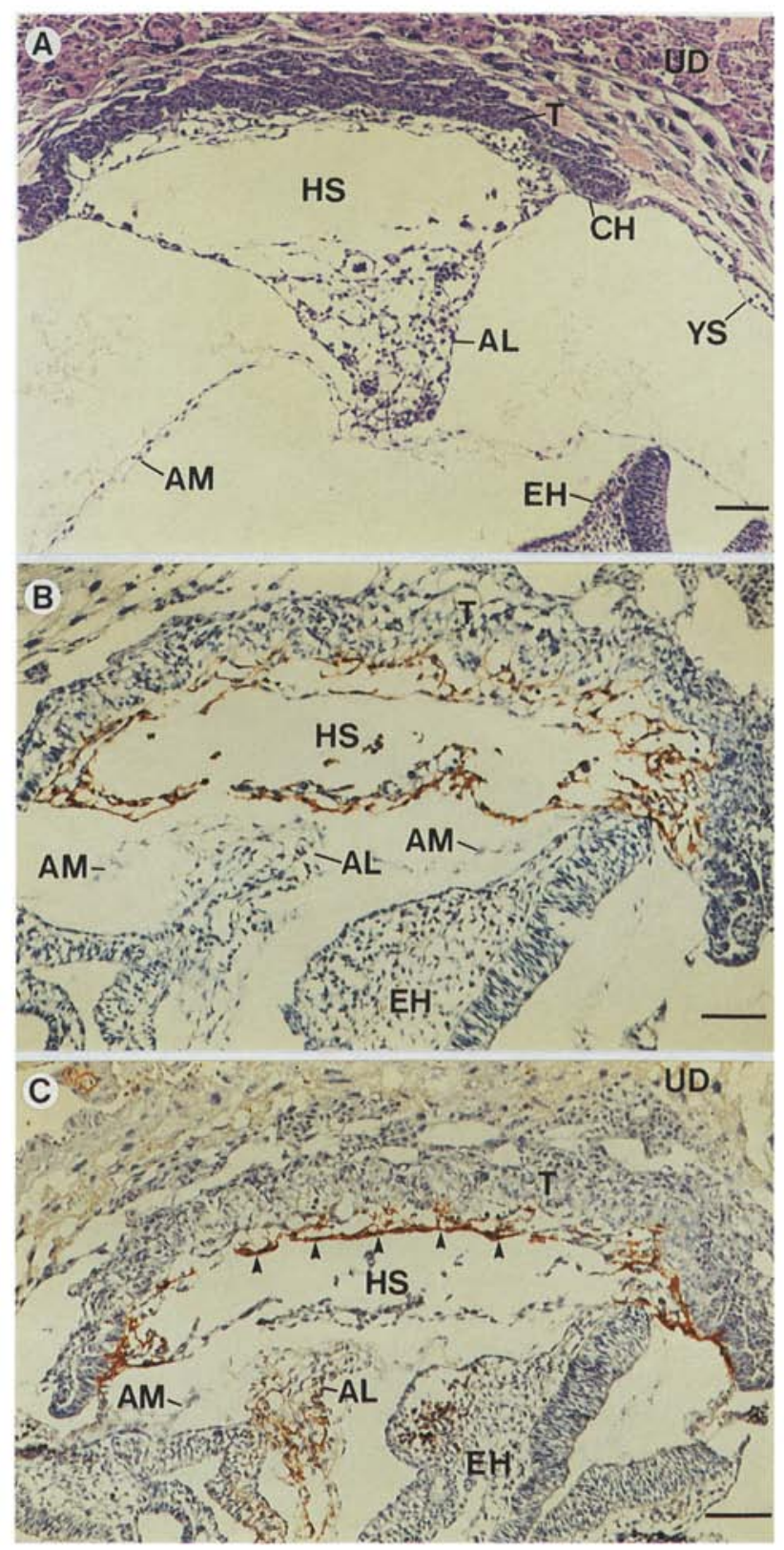

other organs, including skeletal muscle and spleen, did not reveal any abnormalities.

Analysis of circulating leukocytes obtained from orbital blood of VCAM-1-deficient mice revealed an elevated total leukocyte number as compared with wildtype and heterozygous mice $(P<0.05)$. Differential counts determined that this was the result of elevated mononuclear leukocytes, whereas numbers of circulating granulocytes were comparable (Table 2).

\section{Discussion}

\section{Essential role for VCAM-1 in chorioallantoic fusion}

The data presented here demonstrate a novel and essential role for VCAM-1 during embryonic development in 


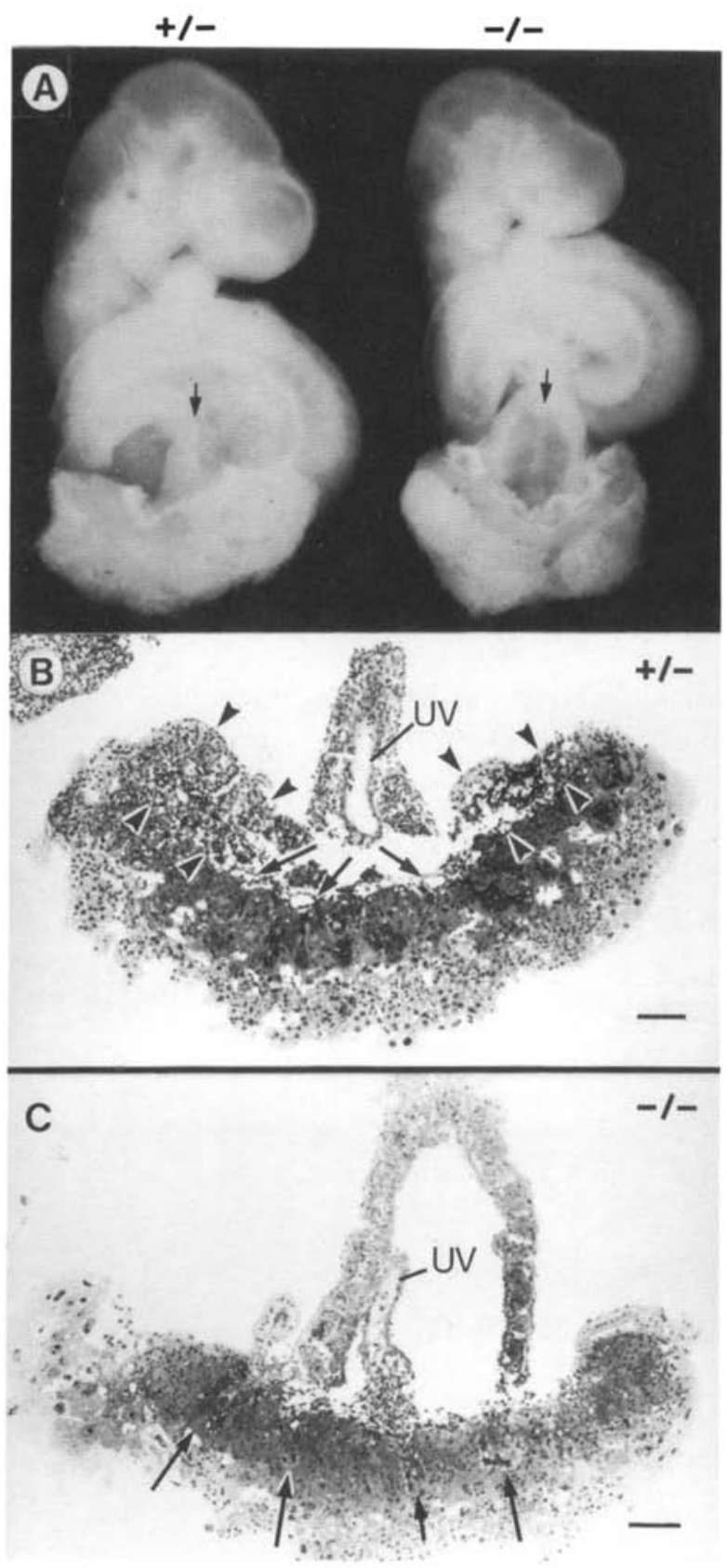

mice. In $>80 \%$ of VCAM-1-deficient embryos, the complete absence of chorioallantoic fusion resulted in embryonic demise by 10-12 days p.c. (Fig. 9). Death was caused by the absence of placental formation, which was established at this time in wild-type embryos (Mossman 1987; Kaufman 1992). Similar results were observed in VCAM-1-deficient mice derived independently by Kwee et al. (1995). Normal embryonic development of viviparous mammals is dependent on the establishment of an efficient maternal-fetal exchange mechanism. Failure of chorioallantoic fusion is a common, though poorly understood, cause of mid-gestational demise. In rodents it can be induced by a variety of agents, including radiation
Figure 5. Placental developmental delay in a 10.0- to 10.5-day VCAM-1-deficient embryo. (A) Littermates at 10.0-10.5 days gestation photographed attached to the chorion. The heterozygous embryo $1+1$ -, left has a normal umbilical cord and blood vessel (arrow), whereas the homozygous VCAM-1-deficient embryo (-/-, right) has a hydropic space surrounding a centrally located vascular structure larrow). (B) Toluidine blue-stained $2-\mu \mathrm{m}$ methacrylate section of the placenta from the heterozygous embryo in $A$, shows allantoic mesoderm spread over the entire placental region (between arrowheads). An umbilical vessel (UV) is present, and blood vessels (arrows), which are derived from the allantoic mesoderm, are found adjacent to the trophoblast. The allantoic mesoderm is invading the trophoblast extensively. (C) The placenta from the VCAM-1-deficient littermate shows a hydropic allantois attached to the chorion. In these regions, allantoic mesoderm is invading into the trophoblast (arrows). The allantoic mesoderm is not distributed over the entire placental surface, and although a central umbilical blood vessel is seen, vascular structures are not evident over the trophoblast. These features represent a placental developmental delay with respect to the embryo. Bars, $100 \mu \mathrm{m}$.

(Kuznetsova 1957; Valshtrem et al. 1960), hypothermia (Tripolskaya et al. 1961), and various pharmaceuticals, such as cyclophosphamide, azaserine (Murphy and Karnovsky 1956), and retinoic acid (Vickers 1985). This may reflect the susceptibility of allantoic mesoderm, which in the period surrounding chorioallantoic fusion is the most rapidly growing and dividing tissue in the developing embryo, to the disparate actions of a variety of agents. In the majority of mammals, chorioallantoic placentation is the only mechanism for maternal-fetal exchange, and its disruption is universally lethal.

The localized expression of VCAM-1 on the allantois and $\alpha 4$ integrin on the chorion during chorioallantoic fusion and placentation suggests that VCAM-1 interacts with its known ligands, $\alpha 4 \beta 1$ and/or $\alpha 4 \beta 7$, during this process. This was confirmed by observations in $\alpha 4$-deficient mice, where a morphologically similar chorioallantoic fusion defect was found (Yang et al. 1995). Receptorligand pairs other than VCAM-1/ $\alpha 4$ integrins may also contribute to chorioallantoic fusion, as fusion occurred in a subset of both VCAM-1- and $\alpha 4$-deficient embryos.

During chorioallantoic fusion, VCAM-1 interactions with $\alpha 4$ integrins may be important in several ways. Adhesive interactions may direct allantoic attachment to the chorion, located on the well-vascularized mesometrial aspect of the uterus, and not to the adjacent yolk sac, as occurs in cultured embryos when the chorion is removed (Fujinaga and Baden 1993). Likewise, VCAM-1 expression on the tip of the allantois may selectively promote fusion of this region. It is also possible that VCAM-1 binding to $\alpha 4$ may initiate cell signaling in the chorion. Our data indicate that VCAM- $1 / \alpha 4$ interactions are not required for the initiation of two distinct allantoic events, which occur following chorioallantoic fusion-hydropic change and mesodermal vascular differentiation-suggesting that other molecular signals are responsible.

\section{VCAM-1 in early placental formation}

We have also demonstrated that following chorioallan- 
Figure 6. Placental developmental delay in a 11.5-day VCAM-1deficient embryo. Methacrylate sections of 11.5-day heterozygous $(A, C)$ and VCAM-1-deficient $(B, D)$ littermates are shown. The placenta of the heterozygous embryo $(+/-)$ has a well-established labyrinth layer $(\mathrm{L}$; shown in detail in $C$ ), allowing maternal-embryo exchange. Abundant embryonic blood vessels (arrowheads) have penetrated deep into the trophoblast (T). These vessels are lined by embryonic endothelial cells with a well-developed basement membrane, contain nucleated erythrocytes, and are adjacent to maternal vascular channels $(\Delta)$. Maternal vascular channels lack endothelium, are lined by trophoblast cells, and contain maternal erythrocytes. Sections of placenta from the VCAM-1-deficient embryo $(-1-)$ show delayed placental development. Although the allantoic mesoderm (ALM) covers the trophoblast $(T)$ and contains vascular structures (arrowheads), there is only minimal invasion of the placental trophoblast layer by allantoic mesoderm and embryonic blood vessels are virtually absent in the trophoblast. Thus, a placental labyrinth layer has not been established. Spaces in the trophoblast are forming maternal vascular channels $(\Delta)$, and some contain maternal erythrocytes. (UV) Umbilical vessels; (UD) uterine decidua. Bar, 100 $\mu \mathrm{m}$.

toic fusion, VCAM-1 is necessary for the efficient distribution of allantoic mesoderm over the entire placental surface. This is an early step in the formation of the placenta and is necessary for normal placental development. The exact role of VCAM-1 in this process is not clear. Adhesive interactions with $\alpha 4$ integrins, expressed over the entire chorionic surface, may act as a "molecular zipper" approximating the allantoic mesoderm to the chorion. These adhesive interactions may allow lateral movement of the allantois on the chorion, resulting in a symmetrical distribution of allantoic mesoderm and evenly distributed placental vasculature. Mechanical forces generated by hydropic swelling of the distal end of the allantois (Ellington 1985) may aid in bringing the allantois into contact with the entire chorionic surface.

In a minority of VCAM-1-deficient embryos, the allantois was able to fuse to the chorion (Fig. 9); however, placental abnormalities were found at 10.5 and 11.5 days gestation and these embryos died by 12.5 days. At 10.0 10.5 days gestation, the allantoic mesoderm was not distributed over the entire chorionic surface, and at 11.5 days, embryonic vascular invasion of the trophoblast layer was minimal. With respect to other organs, these placentas were developmentally delayed, and consequently, the inadequate placental maternal-embryo exchange may have caused developmental defects and subsequent embryonic death. Two possibilities may explain the observed phenotype. If the distal end of the allantois had fused to the chorion at the appropriate time lat 8.5 days p.c.), the absence of VCAM-1/ $\alpha 4$ integrin adhesive interactions could have resulted in abnormal distribution of the allantoic mesoderm over the chorion and delayed placental development. Alternatively, delayed chorioallantoic fusion and hydropic expansion of the allantois prior to fusion could have contributed to the defects. It is also possible that morphologically inapparent functional defects in placental physiology may have existed. These could include alterations of the interhemal

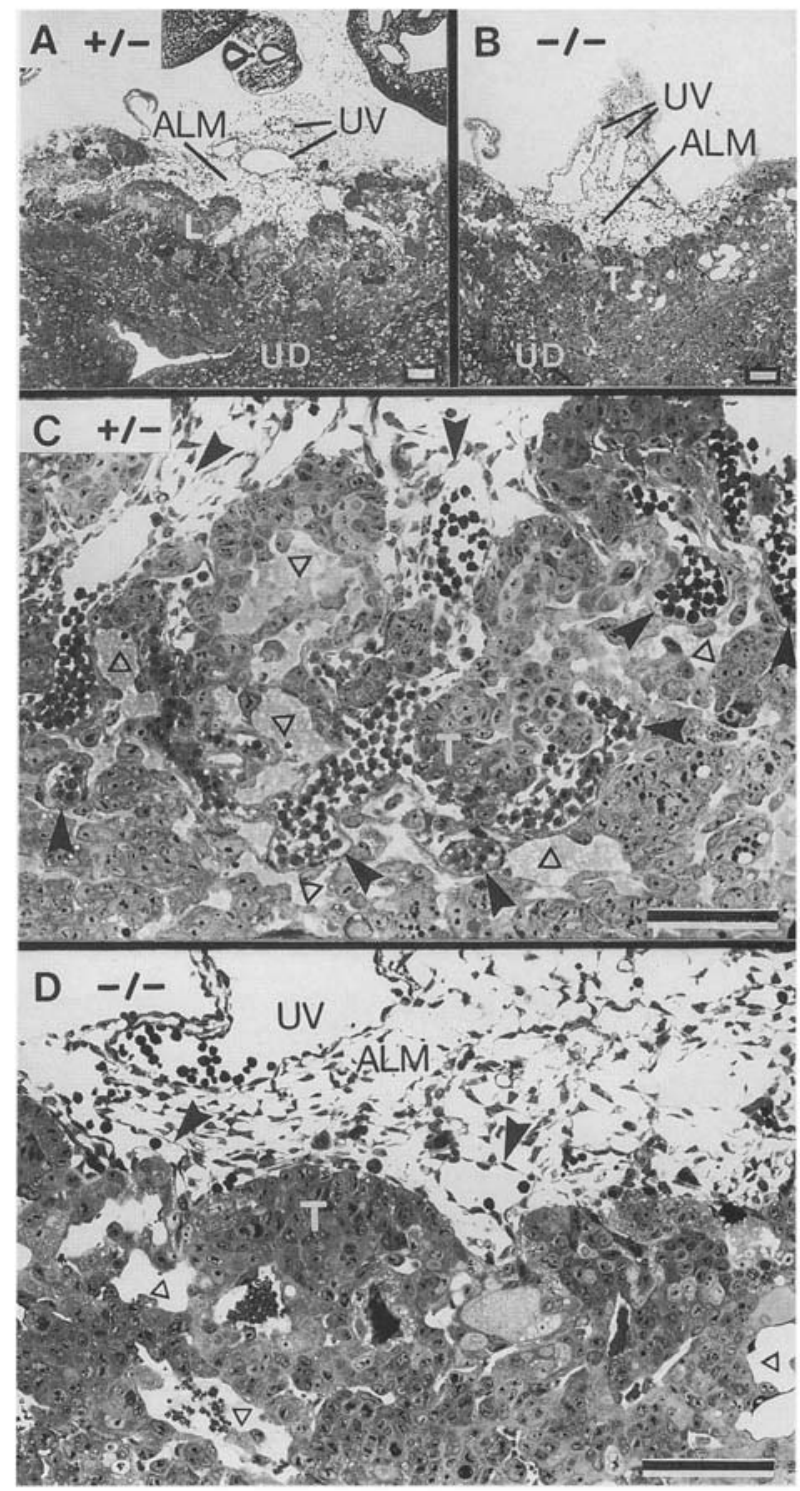

diffusion barrier, dysfunctional regulation of vascular tone, or disruption of the maternal-fetal countercurrent exchange system, all of which could result in embryonic death (Metcalfe et al. 1967; Schroder 1982).

In 11.5-day viable VCAM-1-deficient embryos both with and without chorioallantoic fusion, we found epicardial changes that were similar to those in $\alpha 4$-deficient embryos (Yang et al. 1995.). These consisted of epicardial cell vacuolation, swelling, and focal dissolution. The epicardial changes may have been the result of the absence of VCAM-1 expression in the myocardium or secondary to abnormal or delayed placentation, which we found in these and in 10.5-day embryos. Others have reported cardiac defects secondary to inadequate maternal-fetal exchange. For example, Brachyury embryos, homozygous for mutant $T$ alleles, have defects in mesoderm formation and agenesis of the allantois (Stott et al. 1993). Although the $T$ gene is not expressed during cardiac devel- 


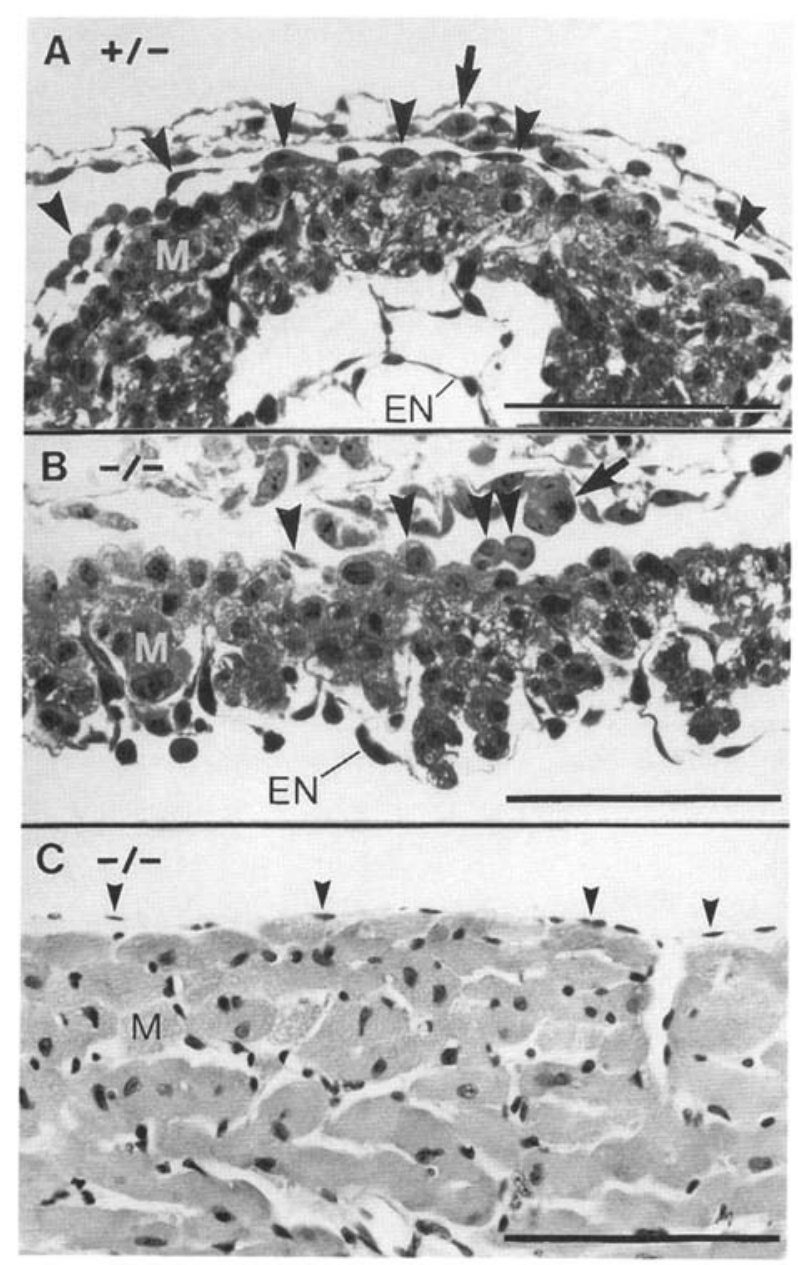

Figure 7. Hearts from VCAM-1-deficient embryos and adult mice. $(A, B)$ Methacrylate sections of the heart from the same 11.5-day heterozygous $(+/-)$ and VCAM-1-deficient $|-/-|$ littermates shown in Fig. 6. Epicardial dissolution is found in the VCAM-1-deficient embryo $(B)$. Only occasional epicardial cells remain (arrowheads), and most appear rounded. The morphologic features of the myocardium (M) and endocardium (EN) are normal. The epicardium in the heterozygous embryo $(A)$ consists of a single contiguous layer of flat cells overlying the entire myocardial surface (arrowheads). Mitotic figures in the thoracic wall are indicated by arrows. Bars, $100 \mu \mathrm{m} .(C)$ Section of heart from an adult VCAM-1-deficient mouse shows normal development of epicardium (arrowheads) and myocardium (M). Bar, 100 $\mu \mathrm{m}$.

opment (Wilkinson et al. 1990), embryos have delayed development of the heart and an enlarged blood-filled pericardial cavity prior to mid-gestational embryonic death (Chesley 1935).

\section{Viable VCAM-1-deficient mice}

We have identified four surviving homozygous VCAM1-deficient mice, which, with the exception of a selective mononuclear leukocytosis, appear phenotypically similar to littermates. Their organs did not reveal any gross or histologic abnormalities, including those in which VCAM-1 has been postulated to play a developmental role, such as skeletal muscle and heart (Rosen et al. 1992; Sheppard et al. 1994). If more than one VCAM1-dependent process is critical to development, the existence of four viable VCAM-1-deficient mice makes it statistically unlikely that a number of infrequent "escape events" serendipitously coincided in these animals. A more likely possibility is that except for placentation, VCAM-1 is not necessary for the normal growth and development of tissues in which it is expressed.

All four surviving VCAM-1-deficient mice were fertile males; however, small numbers preclude conclusions as to whether this sex distribution is significant. The elevated levels of circulating mononuclear leukocytes suggest that VCAM-1/ $\alpha 4$ integrin interactions may be involved in the homeostatic regulation or clearance of these leukocytes. Analogous elevation in numbers of circulating granulocytes have been described in null mutations for other adhesion molecules, including P-selectin and ICAM-1 (Mayadas et al. 1993; Sligh et al. 1993; Xu et al. 1994). Despite this abnormality, VCAM-1-deficient mice appeared healthy.

An unresolved question is how $\sim 3 \%$ of VCAM-1-deficient embryos survived embryonic development. Several possibilities may account for this. One was that some VCAM-1-deficient embryos were able to achieve chorioallantoic fusion and form a placenta with sufficient function to allow survival. Another was that maternally derived soluble VCAM-1 may have diffused into the developing embryo, as has been described in transforming growth factor- $\beta$ (TGF- $\beta$ )-deficient mice (Letterio et al. 1994), was adsorbed onto the allantois, and "rescued" some of the VCAM-1-deficient embryos. Our pilot experiments directed at augmenting soluble maternal VCAM-1 levels by injecting pregnant mice on day 6.5 p.c. with LPS ( $1 \mu$ g i.p.) did not succeed in increasing the survival of VCAM-1-deficient embryos (data not shown).

Because VCAM-1-deficient embryos form normal vitelline vasculature, it is possible that some of them survived by relying partially on a secondary form of placentation unique to rodents, the inverted yolk sac placenta. Because of embryonic turning, developing rodent embryos are enveloped within an extremely well-vascularized inverted yolk sac, which is in direct contact with a large surface area of the uterine decidua (Jollie 1990). This is the primary form of maternal-fetal respiratory exchange until it is superseded by the chorioallantoic placenta (Mossman 1987). Although not invasive, as the definitive chorioallantoic placenta is, it is involved in the acquisition of maternal antibodies (Brambell 1957), vitamin B12 (Padykula et al. 1966), and amino acids (Deren et al. 1966). The importance of yolk sac placentation in rodent development is demonstrated by the observations that intrauterine ligation of vitelline vessels in rats results in embryonic death (Noer and Mossman 1947) and that administration of polyclonal or monoclonal antibodies directed against yolk sac antigens can lead to severe teratogenicity and embryonic demise (Brent et al. 1990). This proposed mechanism may also explain the 
Gurtner et al.
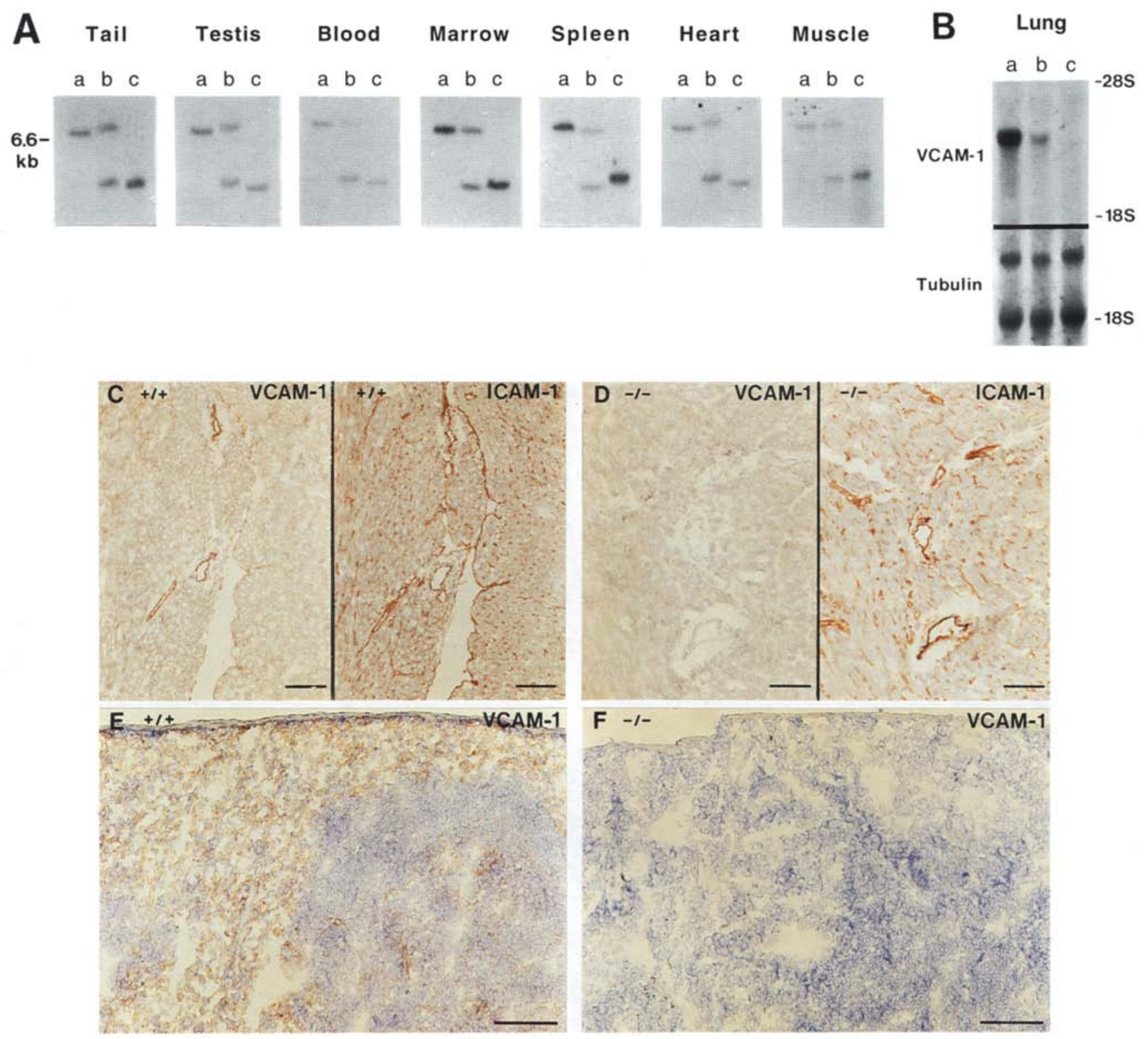

Figure 8. Analysis of a viable adult VCAM-1-deficient mouse. $(A)$ Southern blotting of tissues from wild-type $(a)$, heterozygous $(b)$, and homozygous $(c)$ VCAM-1-deficient mice using the 5' probe illustrated in Fig. 1. Only the mutated VCAM1 allele was detected in the viable VCAM-1-deficient mouse, and PCR analysis also failed to detect the wild-type allele in these tissues. Identical results were obtained with a second viable VCAM-1-deficient mouse (data not shown). (B) Northern blot analysis of RNA harvested from lungs 4 hr after i.p. injection of LPS $(100 \mu \mathrm{g})$. Diminished and absent VCAM-1 mRNA levels are found in heterozygous $(b)$ and homozygous $(c)$ as compared with wild-type $(a)$ VCAM-1-deficient mice. Equal expression of tubulin confirmed equal loading of RNA samples. (C-F) Immunohistochemical staining for VCAM-1 and ICAM-1 expression detected with mAbs MK-2 and YN-1 in hearts $(C, D)$ and spleens $(E, F)$ from wild-type $\{C, E)$ and homozygous VCAM-1-deficient $(D, F)$, mice. In the wild-type mice $(C, E)$, VCAM-1 protein was found in vascular endothelium and endocardium of the heart and in the red pulp, vascular endothelium, and dendritic cells within lymphoid follicles of the spleen. VCAM-1 protein was not detectable in VCAM-1-deficient mice $(D, F)$ and staining was indistinguishable from nonimmune rat immunoglobulin. ICAM-1 expression is identical in tissues from wild-type and VCAM-1-deficient mice, including hearts $(C, D)$ and spleens (data not shown). Bars, $100 \mu \mathrm{m}$.

chronological spectrum of embryonic death that we observe in embryos without chorioallantoic fusion.

Our observations may have important implications for human health and disease. Administration of antiVCAM-1 therapeutics to mothers for inflammatory or immune conditions during the early stages of pregnancy could have dire deleterious consequences for the developing embryo by preventing chorioallantoic fusion in the third week of gestation (Pijnenborg 1981) or subsequent normal placental development. Conversely, inhibition of 
Table 2. Blood leukocyte counts of wild type $(+/+)$, heterozygous $(+/-)$, and homozygous $(-/-)$ VCAM-1-deficient mice

\begin{tabular}{lccc}
\hline & \multicolumn{3}{c}{ Leukocytes/mm $\mathrm{mm}^{3 \mathrm{a}}$} \\
\cline { 2 - 4 } Leukocytes & $+/+(n=6)$ & $+/-(n=6)$ & $-/-(n=4)$ \\
\hline Total & $10,517 \pm 1,565$ & $10,283 \pm 2,771$ & $16,950 \pm 1,936^{\mathrm{b}}$ \\
Mononuclear & $8,413 \pm 1,252$ & $7,797 \pm 2,101$ & $14,704 \pm 1,649^{\mathrm{b}}$ \\
Polymorphonuclear & $2,061 \pm 306$ & $2,484 \pm 669$ & $2,245 \pm 256$ \\
\hline
\end{tabular}

${ }^{a}$ Expressed as mean \pm S.D.

${ }^{\mathrm{b}} P<0.05$ vs. wild-type and heterozygous VCAM-1-deficient mice.

VCAM-1/ $\alpha 4$ integrin interactions in humans $2-4$ weeks after conception may be a way to terminate pregnancy. It is also conceivable that defects in VCAM- $1 / \alpha 4$ interactions may be one of the myriad causes of recurrent spontaneous first trimester abortions and resultant infertility. Because placentation is critical to normal embryonic development, abnormalities of this process can have fatal or life-long consequences. Impaired placental vascularization is believed to be important in acute and chronic placental insufficiency, a major though poorly understood cause of perinatal morbidity and mortality (Fox 1978). In view of the crucial role of VCAM-1 in chorioallantoic fusion and early placental development, it is possible that mutations or deficient expression of the VCAM1 gene can contribute to the pathogenesis of a subset of human placental insufficiencies.

\section{Materials and methods}

\section{Assembly of VCAM1 targeting construct}

Genomic DNA corresponding to the $5^{\prime}$ portion of the murine VCAM1 gene was isolated from a J1 ES cell genomic library kindly provided by Drs. Hong Wu and Rudolf Jaenisch (Whitehead Institute for Biomedical Research and Massachusetts Institute of Technology, Cambridge, MA) (Cybulsky et al. 1993). The targeting construct was assembled from a $6.7-\mathrm{kb}$ EcoRI fragment, containing the core promoter, the signal peptide, and immunoglobulin-like domains 1-3. A $0.4-\mathrm{kb}$ fragment between restriction enzyme sites $B g I I I$ and NheI, which included the majority of domain 1 (exon 2) and a portion of the following intron, was replaced with a NEO cassette in the opposite transcriptional orientation to VCAM1 (Fig. 1A). The neomycin resistance gene was flanked by the murine phosphoglycerate kinase-1 (PGK-1) promoter and the PGK-1 3'-untranslated region with polyadenylation signal (McBurney et al. 1991). Homologous regions $5^{\prime}$ and $3^{\prime}$ of NEO were 2.0 and $4.3 \mathrm{~kb}$, respectively. For negative selection against random integration, a herpes sim- plex virus TK gene, flanked by a mutant polyoma virus enhancer (pMC1-TK; TK) was inserted at the $5^{\prime}$ end of the construct in the $5^{\prime}$ to $3^{\prime}$ orientation (Mansour et al. 1988). A unique NotI restriction site in the pBluescript II KS vector polylinker (Stratagene) was used to linearize the construct for transfection of ES cells. Ligation sites in the targeting construct were verified by restriction enzyme digestion and nucleotide sequencing.

\section{Growth, transfection, and selection of targeted ES cells}

J1 ES cells, derived from 129/terSv mice (Li et al. 1992), were grown on irradiated embryonic feeder cells in HEPES-buffered (20 mM at pH 7.3) Dulbecco's modified Eagle medium (DMEM) supplemented with $15 \%$ fetal bovine serum, $0.1 \mathrm{~mm}$ nonessential amino acids (GIBCO), and $0.1 \mathrm{~mm} 2$-mercaptoethanol. The cells were refed daily. Feeder cells were derived from day 14 embryos and carried the neomycin resistance gene. ES cells were electroporated $\left(1 \times 10^{7}\right.$ cells $\left./ \mathrm{ml}, 25 \mu \mathrm{F}, 400 \mathrm{~V}, 22^{\circ} \mathrm{C}\right)$ with $25 \mu \mathrm{g} / \mathrm{ml}$ of linearized DNA and plated in $100-\mathrm{mm}$ dishes $\left(3 \times 10^{6} \mathrm{cells} / \mathrm{dish}\right)$ on neomycin-resistant embryonic feeder cells. Antibiotic selection was initiated after $24 \mathrm{hr}$ with G418 $(400 \mu \mathrm{g} / \mathrm{ml}$; GIBCO-BRL), followed by G418 and FIAU $(0.2 \mu \mathrm{M}$, Eli Lilly) at $48 \mathrm{hr}$. One plate was selected with G418 alone, allowing estimation of threefold enrichment obtained by FIAU selection. Doubly resistant colonies with appropriate morphologic features were picked 8-10 days after plating, dissociated with trypsin-EDTA, and transferred to 24-well plates, where they were grown without further antibiotic selection. After 3-4 days, half the cells in each well were frozen and DNA was extracted from the remainder.

\section{Generation and breeding of chimeric mice}

Prior to microinjection, ES cell clones carrying the targeted homologous recombination event at one VCAM1 locus were expanded on embryonic fibroblast feeder cells. ES cells (20-25) were microinjected into 3.5-day C57BL/6 or BALB/c blastocysts and surgically implanted into uteri of pseudopregnant foster mothers ( 2.5 days p.c. with vasectomized males). Pups born 17

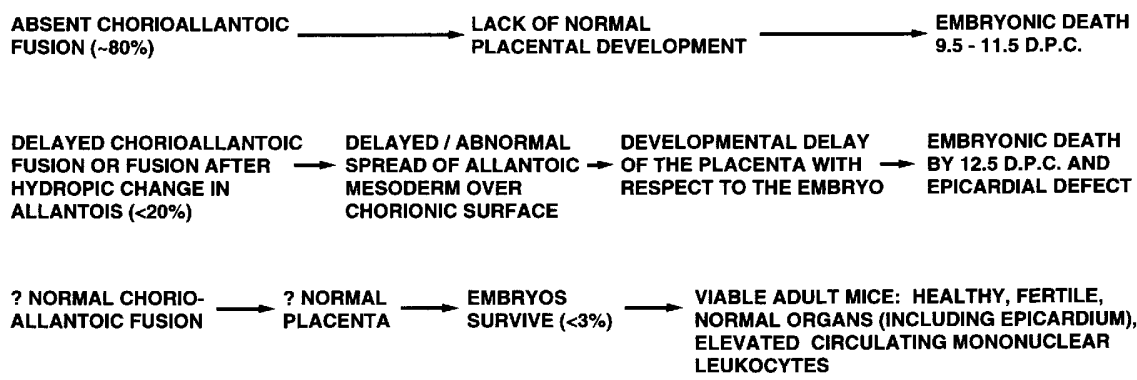

LACK OF NORMAL LACK OF NORMAL
PLACENTAL DEVELOPMENT

EMBRYONIC DEATH

9.5 - 11.5 D.P.C.

$\begin{array}{ll}\text { HYDROPIC CHANGE IN } & \text { MESODERM OVER } \\ \text { ALLANTOIS }(<20 \%) & \text { CHORIONIC SURFACE }\end{array}$

? NORMAL CHORIOALLANTOIC FUSION EMBRYOS
SURVIVE $(<3 \%)$

VIABLE ADULT MICE: HEALTHY, FERTILE, NORMAL ORGANS (INCLUDING EPICARDIUM) ELEVATED CIRCULATING MONONUCLEAR LEUKOCYTES

Figure 9. Spectrum of chorioallantoic fusion/placentation defects in VCAM-1-deficient mice. 
days after injection were identified as chimeric on the basis of agouti coat pigmentation, which was apparent 8-10 days after birth. Chimeric males were mated at 6 weeks of age with C57BL/ 6 or BALB/c females. Germ-line transmission was determined by the presence of agouti coat pigmentation in the $F_{1}$ animals, and tail biopsies were obtained from these mice for genotyping.

\section{Isolation of DNA, Southern blotting,} and polymerase chain reaction

DNA for Southern blotting and polymerase chain reaction (PCR) was isolated by proteinase $\mathrm{K}$ digestion and precipitation with isopropanol (Laird et al. 1991). For yolk sacs and mouse tissues other than tails, a phenol/chloroform [50:50) extraction was included prior to precipitation of DNA. DNA was redissolved in Tris-EDTA buffer.

For Southern blotting, genomic DNA $(\sim 10 \mu \mathrm{g})$ was subjected to restriction enzyme digestion, electrophoresed through $0.8 \%$ agarose gels, and transferred to a BioTrans + (ICN) nylon membrane (Sambrook et al. 1989). Blots were hybridized at $65^{\circ} \mathrm{C}$ with DNA probes labeled with $\left[\alpha^{-32} \mathrm{P}\right] \mathrm{dCTP}$ (DuPont-NEN) using random sequence decanucleotide primers (Amersham). Autoradiography with enhancing screens was performed at $-80^{\circ} \mathrm{C}$.

PCR was performed to genotype embryo yolk sacs and tissues from VCAM-1-deficient adult mice. PCR primers were selected to generate a product specific for either the wild-type or the mutant VCAM1 alleles. Two PCR reactions were performed on each DNA sample and electrophoresed in adjacent lanes. For the wild-type allele, a $0.37-\mathrm{kb}$ PCR product was generated by primers: CCAGCTGTGCTTTGGACACT (located in VCAM1 intron 1) and complementary to TGTGGCTCTGGGTTGCTG, a region of VCAM1 exon 2, which was deleted in the mutant allele. A $0.38 \mathrm{~kb}$ PCR product was generated by primers for the mutant VCAM1 allele: CAGCTGTGTTTGGACACTG in VCAM1 intron 1) and CCAGCTCATTCCTCCACTCAT (in PGK 3'-untranslated region of the NEO cassette). In wild-type mice, a PCR product was found only with primers to the wildtype VCAM1 allele; both PCR products were found in heterozygous mice, and only the PCR product generated by primers to the mutant allele was found in homozygous VCAM-1-deficient mice. Positive and negative controls were run with each analysis and consisted of DNA genotyped by Southern blotting and water. PCR reactions were 30 cycles of denaturation at $94^{\circ} \mathrm{C}$ for $1 \mathrm{sec}$ and $92^{\circ} \mathrm{C}$ for $29 \mathrm{sec}$, annealing at $55^{\circ} \mathrm{C}$ for $30 \mathrm{sec}$ and extension at $72^{\circ} \mathrm{C}$ for $60 \mathrm{sec}$, with a final 8 -min extension. The PCR reaction volumes were $50 \mu \mathrm{l}$ and contained 30 pmoles of each primer, 0.25 units of Taq DNA polymerase (Perkins-Elmer Cetus), and $1.5 \mathrm{mM} \mathrm{MgCl}_{2}$. PCR products were resolved by $1.5 \%$ agarose gel electrophoresis.

\section{Northern blotting}

Total cellular RNA was isolated from tissues by $4 \mathrm{M}$ guanidine isothiocyanate followed by centrifugation through a cesium chloride gradient (Sambrook et al. 1989). Equal amounts of RNA $(10 \mu \mathrm{g} / \mathrm{lane})$ were electrophoresed through a $1 \%$ agarose gel containing formaldehyde, transferred by capillary action to a nylon membrane (BioTrans,$+ \mathrm{ICN}$ ), and hybridized overnight $\left(65^{\circ} \mathrm{C}\right.$ in buffer containing $5 \%$ SDS; Virca et al. 1990) with a ${ }^{32}$-labeled CDNA probe to rat VCAM-1 $(1.8 \mathrm{~kb}$, spanning from immunoglobulin-like domain 2 to the cytoplasmic domain). After stripping, the blot was reprobed with a cDNA probe to rat tubulin.

\section{Timed pregnancies and dissection of embryos}

Timed pregnancies were performed essentially as described by
Rugh (1968). Pregnant female mice were sacrificed, and uteri were removed immediately via an abdominal midline incision. The uteri were immersed in phosphate-buffered saline (PBS), and embryos were dissected under a Nikon SMZ-U stereoscopic zoom microscope equipped with a photographic adapter. Particular attention was given to determine whether chorioallantoic fusion occurred and to examine the placental region. All abnormal embryos were photographed adjacent to normal-appearing littermates. Yolk sacs were dissected for genotyping (7.5 and 8.5 day genotyped by PCR; 8.5 day and older by Southern blotting) and embryos were stored in $10 \%$ buffered formalin.

\section{Histologic and immunohistochemical techniques}

Methacrylate embedding and sectioning were performed as described by Beckstead et al. (1981), with minor modifications. Embryos were fixed with $10 \%$ buffered formaldehyde, dehydrated through a series of graded acetone mixtures, and embedded in glycol methacrylate (JB-4 Plus, Polysciences, Inc.). Sections $2 \mu \mathrm{m}$ in thickness were cut with a glass knife on a LKB ultramicrotome, stained with $0.5 \%$ toluidine blue/ $1 \%$ sodium tetraborate, and coverslipped with Permount.

Immunohistochemical staining was performed essentially as reported previously (Cybulsky and Gimbrone 1991). Embryos were fixed with $2 \%$ paraformaldehyde for $2 \mathrm{hr}$, equilibrated with $8 \%$ then $18 \%$ sucrose in PBS, embedded in OCT compound, and snap-frozen in liquid nitrogen-cooled 2-methylbutane. Adult mouse tissues were embedded fresh in OCT compound. Tissues were stored at $-80^{\circ} \mathrm{C}$. Serial sections were cut on a cryostat, adhered to Vectabond-coated slides, air dried, and fixed for $5 \mathrm{~min}$ in acetone at $-20^{\circ} \mathrm{C}$. Sections were sequentially incubated for $1 \mathrm{hr}$ with primary antibody $(1: 10$ dilution of tissue culture supernatant), biotinylated rabbit antirat $\operatorname{IgG}(1: 200 \mathrm{di}-$ lution, Vector Labs), and avidin-biotin-peroxidase complexes (ABC Elite kit, Vector Labs) diluted 1:100 in Tris-saline. After each incubation, sections were washed three times in Tris-saline, $5 \%$ newborn calf serum. Prior to incubation with avidinbiotin complexes, endogenous peroxidase activity was inactivated with $0.3 \%$ hydrogen peroxide in PBS. Peroxidase activity was detected with 3-amino-9-ethylcarbazole (Sigma), sections were counterstained with Gill's hematoxylin \#2, and mounted in glycerol gelatin. Rat monoclonal antibodies to murine VCAM-1 (MK-2), ICAM-1 (YN-1), and $\alpha 4$ integrin (PS-2) were obtained from the American Type Culture Collection. Nonimmune rat IgG $(0.3 \mu \mathrm{g} / \mathrm{ml}$; Caltag $)$ was used as a negative control.

\section{Hematological studies}

Mice were anesthetized with tribromoethanol $10.3 \mathrm{mg} / \mathrm{g}$ i.p. $)$ and bled from the retro-orbital plexus using heparinized capillary tubes. Leukocyte counts were performed by hemocytometer after dilution of whole blood in Turk's solution (methyl violet in $1 \%$ acetic acid). Differential leukocyte counts were performed on peripheral blood smears stained with WrightsGiemsa (Harleco). At least 200 cells were counted per smear. For statistical analysis, groups were compared using an unpaired $t$-test, and a $P$ value of $<0.05$ was used to denote significance.

\section{Acknowledgments}

We thank Dr. Elisabeth George for assistance with initial embryo dissections, providing histologic sections of wild-type embryos, and many helpful discussions, George Stavrakis and Kaeko Iiyama for technical assistance with histologic techniques, Lina Du for assistance with ES cell microinjection, and 
Ramzi Cotran, Michael Gimbrone, and Tanya Mayadas-Norton for critical review of the manuscript and helpful commentary. G.C.G. was supported by the Robert R. Linton Fellowship for Vascular Research from the Department of Surgery at the Massachusetts General Hospital. A.S. is a Scholar of the Lucille P. Markey Foundation. This work was supported by National Institutes of Health grants HL 45563 and HL 36028.

The publication costs of this article were defrayed in part by payment of page charges. This article must therefore be hereby marked "advertisement" in accordance with 18 USC section 1734 solely to indicate this fact.

\section{References}

Beckstead, J.H., P.S. Halverson, C.A. Ries, and D.F. Bainton. 1981. Enzyme histochemistry and immunochemistry on biopsy specimens of pathologic human bone marrow. Blood 57(6): 1088-1098.

Brambell, F.W. 1957. The passive immunity of the young mammal. Biol. Rev. 33: 488-531.

Brent, R.L., D.A. Beckman, M. Jensen, and T.R. Koszalka. 1990. Experimental yolk sac dysfunction as a model for studying nutritional disturbances in the embryo during early organogenesis. Teratology 41: 405-413.

Briscoe, D.M., F.J. Schoen, G.E. Rice, and M.P. Bevilacqua. 1991. Induced expression of endothelial-leukocyte adhesion molecules in human cardiac allografts. Transplantation 51: 537-539.

Burkly, L.C., A. Jakubowski, B.M. Newman, M.D. Rosa, G. ChiRosso, and R.R. Lobb. 1991. Signalling by vascular cell adhesion molecule-1 (VCAM-1) through VLA-4 promotes CD3 dependent T-cell proliferation. Eur. J. Immunol. 21: 28712875.

Carlos, T.M., B.R. Schwartz, E.Y. Kovach, M. Rosso, L. Osborn, G. Chi-Russo, B. Newman, R. Lobb, and J.M. Harlan. 1990. Vascular cell adhesion molecule-1 mediates lymphocyte adherence to cytokine activated cultured human endothelial cells. Blood 76: 965-970.

Chan, B.M., M.J. Elices, E. Murphy, and M.E. Hemler. 1992. Adhesion to vascular adhesion molecule 1 and fibronectin. Comparison of alpha 4 beta 1 and alpha 4 beta 7 on the human cell line JY. I. Biol. Chem. 267(12): 8366-8370.

Chesley, P. 1935. Development of the short-tailed mutant in the house mouse. I. Exp. Zool. 70: 429-459.

Cinquetti, R. 1983. Histologic changes in chorioallantoic placenta of the mouse with increasing gestational age. Arch. Ital. Anat. Embriol. 88: 267-278.

Cybulsky, M. and M. Gimbrone. 1991. Vascular endothelial cells express a monocyte adhesion molecule during atherogenesis. Science 251: 788-791.

Cybulsky, M.I., J.W.U. Fries, A.J. Williams, P. Sultan, V.M. Davis, M.A. Gimbrone, Jr., and T. Collins. 1991. Gene structure, chromosomal location, and basis for alternative mRNA splicing of the human VCAM-1 gene. Proc. Natl. Acad. Sci. 88: 7859-7863.

Cybulsky, M., M. Allan-Motamed, and T. Collins. 1993. Structure of the murine VCAM1 gene. Genomics 18: 387-391.

Damle, N.K. and A. Aruffo. 1991. Vascular cell adhesion molecule-1 induces T-cell antigen receptor-dependent activation of CD4+ lymphocytes. Proc. Natl. Acad. Sci. 88: 64036407.

Damsky, C.H., J. Richa, D. Solter, B. Knowles, K. Knudsen, and C.A. Buck. 1983. Identification and purification of a cell surface glycoprotein involved in cell-cell interactions. Cell 34: 455-466.
Damsky, C., A. Sutherland, and S. Fisher. 1993. Extracellular matrix 5 ; adhesive interactions in early mammalian embryogenesis, implantation and placentation. FASEB 1 . 7: $1320-1329$.

Deren, J.J., H.A. Padykula, and T.H. Wilson. 1966. Development of amino acid transport by rabbit yolk sac. Dev. Biol. 13: 349-384.

Elices, M.J., L. Osborn, Y. Takada, C. Crouse, S. Luhowskyi, M.E. Hemler, and R. Lobb. 1990. VCAM-1 on activated endothelium interacts with the leukocyte antigen VLA-4 at a site distinct from the VLA-4/fibronectin binding site. Cell 60: $577-584$.

Ellington, S.K. 1985. A morphological study of the development of the allantois of rat embryos in vivo. J. Anat. 142: 1-11.

Fox, H. 1978. Histological abnormalities of the placenta. In $\mathrm{Pa}$ thology of the placenta, pp. 149-197. W.B. Saunders, Philadelphia, PA.

Freedman, A.S., J.M. Munro, G.E. Rice, M.P. Bevilacqua, C. Morimoto, B.W. McIntyre, K. Rhynhart, J.S. Pober, and L.M. Nadler. 1990. Adhesion of human B cells to germinal centers in vitro involves VLA-4 and INCAM-110. Science 249: 1030.

Fujinaga, M. and J.M. Baden. 1993. Microsurgical study on the mechanisms determining sidedness of axial rotation in rat embryos. Teratology 47(6): 585-593.

Jollie, W.P. 1990. Development, morphology, and function of the yolk-sac placenta of laboratory rodents. Teratology 41: 361-381.

Kaufman, M.H. 1992. The atlas of mouse development, pp. 5-17. Academic Press, San Diego, CA.

Kovats, S., E.K. Main, C. Librach, M. Stubblebine, S.J. Fisher, and R. DeMars. 1990. A class I antigen, HLA-G, expressed in human trophoblasts. Science 248: 220-223.

Kuznetsova, M.N. 1957. Histopathology of the placenta in radiation sickness. Akush. Ginekol. (Mosc.) 33/4: 50-55.

Kwee, L., S. Baldwin, C.W. Stewart, C. Buck, and M.A. Labow. 1995. Defective development of the embryonic and extraembryonic circulatory systems in vascular cell adhesion molecule (VCAM-1) deficient mice. Development (in press).

Laird, P.W., A. Zijderveld, K. Linders, M.A. Rudnicki, R. Jaenisch, and A. Berns. 1991. Simplified mammalian DNA isolation procedure. Nucleic Acids Res. 19: 4293.

Larue, L., M. Ohsugi, J. Hirchenhain, and R. Kemler. 1994. E-cadherin null mutant embryos fail to form a trophectoderm epithelium. Proc. Nat1. Acad. Sci. 91: 8263-8267.

Letterio, J.J., A.G. Geiser, A.B. Kulkarni, N.S. Roche, M.B. Sporn, and A.B. Roberts. 1994. Maternal rescue of transforming growth factor- $\beta 1$ null mice. Science 264: 1936-1938.

Li, E., T.H. Bestor, and R.A. Jaenisch. 1992. Targeted mutation of the DNA methyltransferase gene results in embryonic lethality. Cell 69: 915-926.

Li, H., M.I. Cybulsky, M.A. Gimbrone, Jr., and P. Libby. 1993. Inducible expression of vascular cell adhesion molecule-1 (VCAM-1) by vascular smooth muscle cells in vitro and within rabbit atheroma. Am. J. Pathol. 143: 1551-1559.

Mansour, S.L., K.R. Thomas, and M.R. Capecchi. 1988. Disruption of the proto-oncogene int-2 in mouse embryo-derived stem cells: A general strategy for targeting mutations to nonselectable genes. Nature 336: 348-352.

Mayadas, T.N., R.C. Johnson, H. Rayburn, R.O. Hynes, and D.D. Wagner. 1993. Leukocyte rolling and extravasation are severely compromised in p-selectin-deficient mice. Cell 74: 541-554.

McBurney, M.W., L.C. Sutherland, C.N. Adra, B. LeClair, M.A. Rudnicki, and K. Jardine. 1991. The mouse Pgk-1 gene promoter contains an upstream activator sequence. Nucleic Acids Res. 19: 5755-5761. 
McMahon, A.P. and A. Bradley. 1990. The Wnt-1 (int-1) protooncogene is required for development of a large region of the mouse brain. Cell 62: 1073-1085.

Metcalfe, J., H. Bartels, and W. Moll. 1967. Gas exchange in the pregnant uterus. Physiol. Rev. 47: 782-838.

Miyake, K., K. Medina, K. Ishihara, M. Kimoto, R. Auerbach, and P.W. Kincade. 1991. A VCAM-1 like adhesion molecule on murine bone marrow stromal cells mediates binding of lymphocyte precursors in culture. J. Cell Biol. 114: 557-565.

Mossman, H.W. 1987. Vertebrate fetal membranes, pp.1-10, 84-113, 216-249. Rutgers University Press, New Brunswick, NJ.

Murphy, M.L. and D.A. Karnovsky. 1956. Effect of azaserine and other growth inhibiting agents on fetal development in the rat. Cancer 9: 955-962.

Noer, H.R. and H.W. Mossman. 1947. Surgical investigation of the inverted yolk sac placenta of the rat. Anat. Rec. 98: 3138.

O'Brien, K.D., M.D. Allen, T.O. McDonald, A. Chait, J.M. Harlan, D. Fishbein, J. McCarty, M. Ferguson, K. Hudkins, C.D. Benjamin, R. Lobb, and C.E. Alpers. 1993. Vascular cell adhesion molecule-1 is expressed in human coronary atherosclerotic plaques. Implications for the mode of progression of advanced coronary atherosclerosis. J. Clin. Invest. 92: 945951.

Ogura, A., T. Nishida, Y. Hayashi, and K. Mochida. 1991. The development of the uteroplacental vascular system in the golden hamster. Mesocricetus auratus. J. Anat. 175: 65-77.

Osborn, L., C. Hession, R. Tizard, C. Vassallo, S. Luhowskyj, G. Chi-Rosso, and R. Lobb. 1989. Direct expression cloning of vascular cell adhesion molecule 1 , a cytokine-induced endothelial protein that binds to lymphocytes. Cell 59: 12031211.

Osborn, L., C. Vassallo, and C.D. Benjamin. 1992. Activated endothelium binds lymphocytes through a novel binding site in the alternately spliced domain of vascular cell adhesion molecule-1. J. Exp. Med. 176: 99-107.

Padykula, H., J. Deren, and H. Wilson. 1966. Development of structure and function in the mammalian yolk sac. Dev. Biol. 13: 311-348.

Pijnenborg, R., W.B. Robertson, I. Boxins, and G. Dixon. 1981. Review article: Trophoblast invasion and the establishment of haemochorial placentation in man and laboratory animals. Placenta 2: 71-91.

Rice, G.E., J.M. Munro, C. Corless, and M.P. Bevilacqua. 1991. Vascular and nonvascular expression of INCAM-110. Am. J. Pathol. 138: 385-393.

Rosen, G.D., J.R. Sanes, R. LaChance, J.M. Cunningham, J. Roman, and D.C. Dean. 1992. Roles for the integrin VLA-4 and its counter receptor in myogenesis. Cell 69: 1107-1119.

Rossant, J. and B.A. Croy. 1985. Genetic identification of tissue of origin of cellular populations within the mouse placenta. J. Embryol. Exp. Morphol. 86: 177-189.

Rugh, R. 1968. The mouse, its reproduction and development, pp. 46-55. Oxford University Press, Oxford, U.K.

Sambrook, J., E.F. Fritsch, and T. Maniatis. 1989. Molecular cloning: A laboratory manual, pp. 7.19-7.22. Cold Spring Harbor Laboratory Press, Cold Spring Harbor, N.Y.

Schroder, H. 1982. Structural and functional organization of the placenta from the physiological point of view. Bibl. Anat. 22: 4-12.

Sheppard, A.M., M.D. Onken, G.D. Rosen, P.G. Noakes, and D.C. Dean. 1994. Expanding roles for $\alpha 4$ and its ligands in development. Cell Adhesion Commun. 1: 27-43.

Simmons, P.J., B. Masinovsky, B.M. Longenecker, R. Berenson, B. Torok-Storb, and W.M. Gallatin. 1992. Vascular cell ad- hesion molecule- 1 expression by bone marrow cells mediates the binding of hematopoietic progenitor cells. Blood 80: $388-395$

Sligh, J.E., C.M. Ballantyne, S.S. Rich, H.K. Hawkins, C.W. Smith, A. Bradley, and A.L. Beaudet. 1993. Inflammatory and immune responses are impaired in mice deficient in intercellular adhesion molecule 1. Proc. Nat1. Acad. Sci. 90: 8529-8533.

Stott, D., A. Kispert, and B.G. Herrmann. 1993. Rescue of the tail defect of Brachyury mice. Genes \& Dev. 7: 197-203.

Theiler, K.T. 1989. The house mouse: Atlas of embryonic development, pp. 51, 61, 65. Springer-Verlag, New York.

Thomas, K.R. and M.R. Capecchi. 1987. Site-directed mutagenesis by gene targeting in mouse embryo-derived stem cells. Cell 51: 503-512.

Tripolskaya, N.A. 1961. Effect of cooling at early stages of gestation on the development of the placenta in the rat. Arkh. Anat. Gistol. Embriol. 41: 19-27.

Valshtrem, E.A. 1960. Pathogenesis of irridation injury and reparative processes in rat embryos after $x$-radiation on the 10th day of pregnancy. Arkh. Anat. Gistol. Embriol. 38: 7279.

van Seventer, G.A., W. Newman, Y. Shimuzu, T.B. Nutman, Y. Tanaka, K.J. Horgan, T.V. Gopal, E. Ennis, D. O'Sullivan, H. Grey, and S. Shaw. 1991. Analysis of T-cell stimulation by superantigen plus major histocompatability complex class II molecules or by CD3 monoclonal antibody: Costimulation by purified adhesion ligands VCAM-1, ICAM-1, but not ELAM-1. J. Exp. Med. 174: 901-913.

Vickers, T.H. 1985. Embryolethality in rats caused by retinoic acid. Teratology 31: 19-33.

Virca, G.D., W. Northemann, B.R. Shiels, G. Widera, and S. Broome. 1990. Simplified northern blot hybridization using $5 \%$ sodium dodecyl sulfate. BioTechniques 8: 370-371.

Welsh, A.O. and A.C. Enders. 1993. Chorioallantoic placenta formation in the rat . (iii). Granulated cells invade the uterine luminal epithelium at the time of epithelial cell death. Biol. Reprod. 49: 38-57.

Wilkinson, D.G., S. Bhatt, and B.G. Herrmann. 1990. Expression pattern of the mouse $T$ gene and its role in mesoderm formation. Nature 343: 657-659.

Xu, H., J.A. Gonzalo, Y. St. Pierre, I.R. Williams, T.S. Kupper, R.S. Cotran, T.A. Springer, and J.-C. Gutierrez-Ramos. 1994. Leukocytosis and resistance to septic shock in intercellular adhesion molecule-1-deficient mice. J. Exp. Med. 180: 95109.

Yang, J.T., H. Rayburn, and R.O. Hynes. 1995. Cell adhesion events mediated by $\alpha 4$ integrins are essential in placental and cardiac develpoment. Development (in press). 


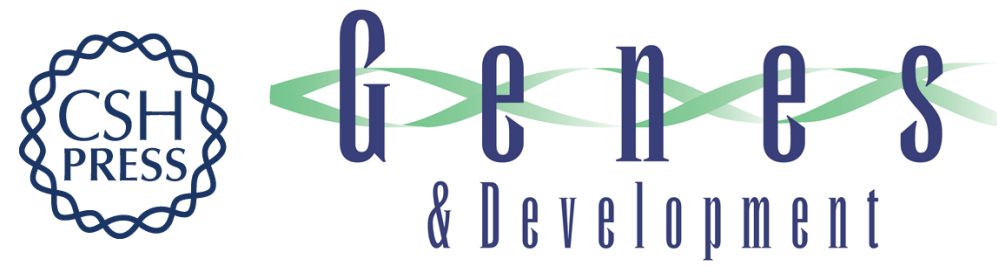

\section{Targeted disruption of the murine VCAM1 gene: essential role of VCAM-1 in chorioallantoic fusion and placentation.}

G C Gurtner, V Davis, H Li, et al.

Genes Dev. 1995, 9:

Access the most recent version at doi:10.1101/gad.9.1.1

References This article cites 59 articles, 17 of which can be accessed free at:

http://genesdev.cshlp.org/content/9/1/1.full.html\#ref-list-1

License

Email Alerting

Service

Receive free email alerts when new articles cite this article - sign up in the box at the top right corner of the article or click here.

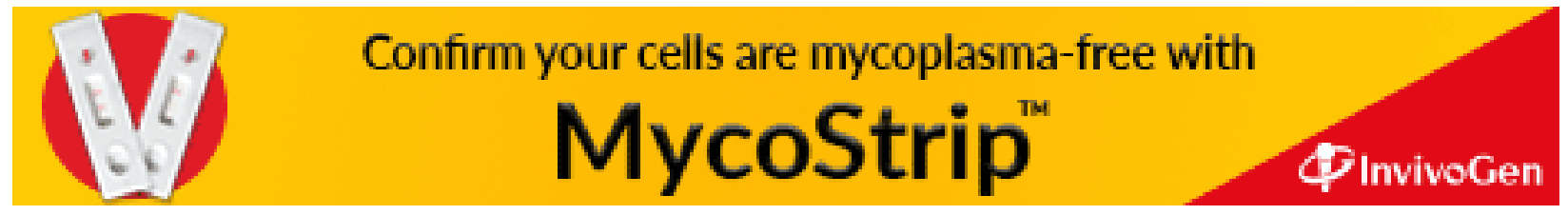

